\title{
Karyotype Analysis and Relationships Among Varieties of Arachis hypogaea L. ${ }^{1}$
}

\author{
H. T. Stalker and R. D. Dalmacio \\ Department of Crop Science, North Carolina State University, \\ Raleigh, NC 27695, U.S.A.
}

Accepted July 20, 1985

The cultivated peanut, Arachis hypogaea L., is an allotetraploid species $(2 n=$ 40) grown in tropical and warm temperate regions. Peanuts are rich in both oil and protein and make a major contribution to human nutrition. Arachis hypogaea is a highly variable species with a primary center of origin in southern Bolivia or northern Argentina (Gregory and Gregory 1976). Krapovickas (1969, 1973) described five secondary centers of diversity which are to some extent characteristic of peanut varieties. A tertiary center of diversity also exists in Africa (Gibbons et al. 1972). The species has been subdivided into two subspecies (Table 1) and evidence for some genetic isolation between the groups exists (Krapovickas 1973, Wynne 1974). Each subspecies has two varieties (Krapovickas 1969, 1973) as follows: subsp. hypogaea var. hypogaea and var. hirsuta and subsp. fastigiata var. fastigiata and var. vulgaris. In addition, var. nambyquarae was given varietal status by Gregory et al. (1973), but its classification as a unique group versus a type of var. hypogaea is still unresolved because subsequent publications by Gregory and Gregory (1976), Gregory et al. (1973) and Wynne and Gregory (1980) follow the convention of only four $A$. hypogaea varieties.

The chromosomes of $A$. hypogaea are small and mostly metacentric (Ghimpu 1930). Husted $(1933,1936)$ observed a distinctively small chromosome pair plus a chromosome pair with a secondary constriction. However, he was unable to differentiate the other A. hypogaea chromosomes. Babu (1955) later reported several types of secondary constrictions in peanut cultivars and D'Cruz and Tankasale (1961) cytologically distinguished four peanut cultivars. Singh and Moss (1982) also illustrated karyotypes of $A$. monticola and two $A$. hypogaea cultivars and showed differences among genotypes.

Arachis hypogaea probably originated from a wild allotetraploid species (Krapovickas and Rigoni 1957, Smartt and Gregory 1967). Since A. monticola Krap. et Rig. grows near the proposed center of origin and is the only other tetraploid species cross-compatible with $A$. hypogaea, it is the most likely progenitor of the cultivated peanut (Krapovickas 1973). Furthermore, diploid ancestors of $A$. hypogaea probably belong to section Arachis of the genus since only this group of species will hybridize with the cultigen (Gregory and Gregory 1976, Smartt et al. 1978a, b). Arachis hypogaea has an A and B genome which corresponds to the genomic make-up of diploid species of section Arachis (Smartt et al. 1978a, b).

1 Paper no. 8385 of the journal series of the North Carolina Agricultural Research Service, Raleigh, NC 27695. The investigation was supported by SEA-CR grant no. 79-59-2371-1-1-367-1. 
Most diploid species of section Arachis have the A genome while A. batizocoi is the only one known with a B genome (Smartt et al. 1978a, Stalker and Dalmacio 1981). Although several species have been suggested as progenitors of $A$. hypogaea, according to Smartt and Stalker 1982, the true ancestors have not been positively identified.

The objective of this investigation was to identify the morphology of $A$. hypogaea chromosomes to derive a standard karyotype for the cultivated species. Variability among varieties of $A$. hypogaea was then evaluated. The karyotypes of $A$. hypogaea and $A$. monticola were also compared to the chromosomes of diploid species of section Arachis to identify possible progenitors of the cultivated species.

\section{Materials and methods}

Nine cultivars of $A$. hypogaea $(2 n=40)$, including representatives of the four botanical varieties plus two collections of $A$. monticola $(2 n=40)$ were karyotyped (Table 1). Both cultivars grown in the USA and unimproved genotypes from South

Table 1. Subspecific classification of $A$. hypogaea L. after Krapovickas (1969) and germplasm cytologically analyzed

\begin{tabular}{|c|c|c|c|c|}
\hline Name & Type & Differences & $\begin{array}{l}\text { Collection } \\
\text { analyzed }\end{array}$ & Origin \\
\hline Subsp. hypogaea & 一 & $\begin{array}{l}\text { Reproductive axis absent } \\
\text { on main stem; alternating } \\
\text { pairs of reproductive and } \\
\text { vegetative axis on lateral } \\
\text { branches }\end{array}$ & & \\
\hline \multirow[t]{3}{*}{ var. hypogaea } & \multirow[t]{3}{*}{ Virginia } & \multirow{3}{*}{$\begin{array}{l}\text { Short branches with little } \\
\text { pubescence }\end{array}$} & $\mathrm{NC} 4$ & USA \\
\hline & & & NC 6 & USA \\
\hline & & & Nambyquarae & NW Brazil \\
\hline var. hirsuta & $\begin{array}{l}\text { Peruvian } \\
\text { runner }\end{array}$ & Long pubescent branches & PI 158850 & China \\
\hline Subsp. fastigiata & - & $\begin{array}{l}\text { Reproductive axis on main } \\
\text { stem, continuous runs of } \\
\text { reproductive axis on lateral } \\
\text { branches }\end{array}$ & & \\
\hline \multirow[t]{2}{*}{ var. fastigita } & \multirow[t]{2}{*}{ Valencia } & \multirow[t]{2}{*}{ Little branched } & Tennessee Red & USA \\
\hline & & & NC Acc. 17090 & Paraguay \\
\hline \multirow[t]{3}{*}{ var. vulgaris } & \multirow[t]{3}{*}{ Spanish } & \multirow{3}{*}{$\begin{array}{l}\text { More branched, small } \\
\text { seeds }\end{array}$} & Argentine & USA \\
\hline & & & Spanhoma & USA \\
\hline & & & PI 262000 & Paraguay \\
\hline \multirow[t]{2}{*}{ A. monticola } & \multirow[t]{2}{*}{-} & \multirow[t]{2}{*}{ Biarticulated fruit } & Coll. K7264 & NW Argentina \\
\hline & & & $\begin{array}{l}\text { Coll. GKBSPSc } \\
30062\end{array}$ & NW Argentina \\
\hline
\end{tabular}

America were analyzed to estimate variability within varieties. Root tips were collected from seedlings germinated in sand. Materials were pretreated 15 minutes in a saturated solution of paradichlorobenzene, hydrolyzed in $1 \mathrm{~N} \mathrm{HCl}$, stained in $2 \%$ aceto-orcein for 1 hour, squashed in an oil press at $211 \mathrm{~kg} / \mathrm{cm}^{2}$, dehydrated in an alcohol series after removal of cover slips, and permanently mounted with Per- 
mount. Observations were from cells in the early metaphase stage of mitosis. Fifteen cells were analyzed for each genotype and standard errors calculated. Photomicrographs were taken of all cells and printed at $4000 \times$. Chromosomes were then cut from photomicrographs, homologues paired based on heterochromatic regions, differential staining of chromosome arms, chromosome lengths and centromere positions, and then ordered from 1 to 20 based on chromosome morphology and total length. The longest chromosome was designated number 1 and the shortest chromosome was number 20 . The length of the short and long chromosome arms was recorded and three centromere-position types designated as follows: 0.80 to $1.00=$ median, 0.65 to $0.79=$ slightly submedian, and 0.33 to $0.64=$ submedian. A principal component analysis of the nine $A$. hypogaea genotypes plus $A$. monticola was conducted using the calculated short/long chromosome arm ratios to better estimate similarities among collections.

\section{Results}

The homologues within single cells of most analyzed genotypes were relatively easy to pair based on absolute length, centromere position and differential staining of heterochromatic regions. Although absolute chromosome lengths appear nearly as a continuum from 1 through 20 , the six to nine asymmetrical chromosomes interspersed throughout the genome made ordering the homologues possible. When two chromosomes had nearly identical lengths, they were arbitrarily, but consistently, ordered within each cultivar so that one was designated as the shorter chromosome of the set. However, several chromosome pairs had very similar lengths and morphology and they were nearly impossible to differentiate, for example, chromosomes 7 and 8 or 13,14 and 15. Although care was taken to analyze cells at the same stage of mitosis, the average length of chromosome 1 ranged from $3.33 \mu \mathrm{m}$ for Spanhoma to $4.16 \mu \mathrm{m}$ for PI 158850. When the ratio of chromosomes $1: 20$ was calculated for the 10 gentotypes, the range was 2.05 to $2.38 \quad(\mathrm{avg}=2.22)$. The variation in absolute lengths among the genotypes is believed to be attributable to different chromosome condensation rates among the genotypes. Karyotypes of representative collections of each botanical variety of $A$. hypogaea plus $A$. monticola are presented in Figs. 1, 2. Chromosome measurements, including absolute lengths and short/long arm ratios, are presented in Tables 2 and 3; and karyotypic variation among the 10 analyzed genotypes is illustrated in Table 4.

The karyotypes of the $9 A$. hypogaea cultivars varied more among than within varieties (Fig. 3; Table 4). A principal component analysis (Fig. 3) illustrates the karyotypic relationships among cultivars and varieties. Varieties vulgaris, fastigiata, hirsuta, and hypogaea formed distinct groups. Intermediate to varieties vulagris and hypogaea was the variety hirsuta; and nambyquarae clustered with var. fastigiata even though it is a member of subsp. hypogaea.

The three var. vulgaris genotypes (Argentine, Spanhoma and PI 262000) had very similar karyotypes except for the chromosome with a secondary constriction. Argentine had a secondary constriction on chromosome 11 while PI 262000 and Spanhoma had the secondary constriction on chromosomes 6 and 7 , respectively 


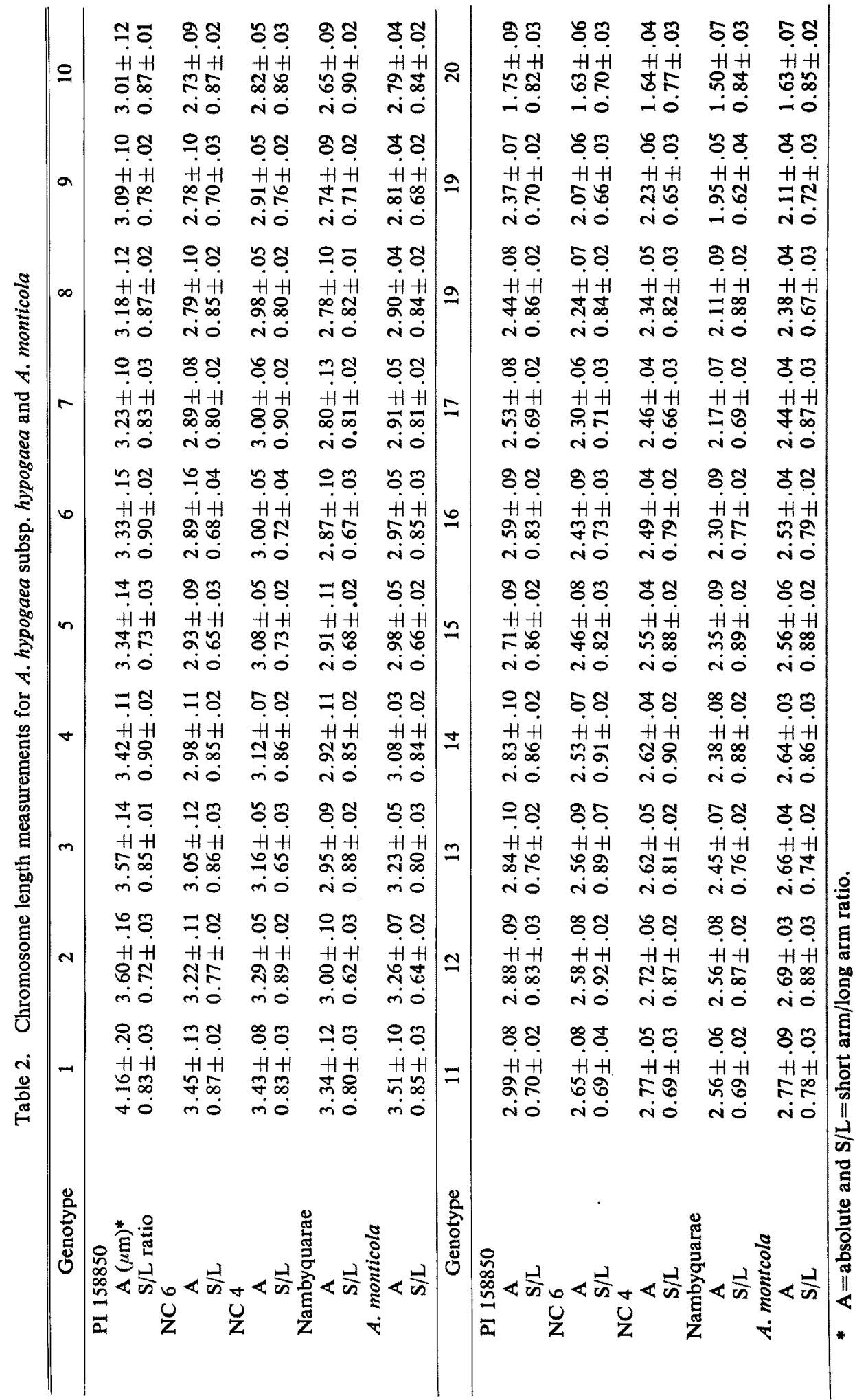




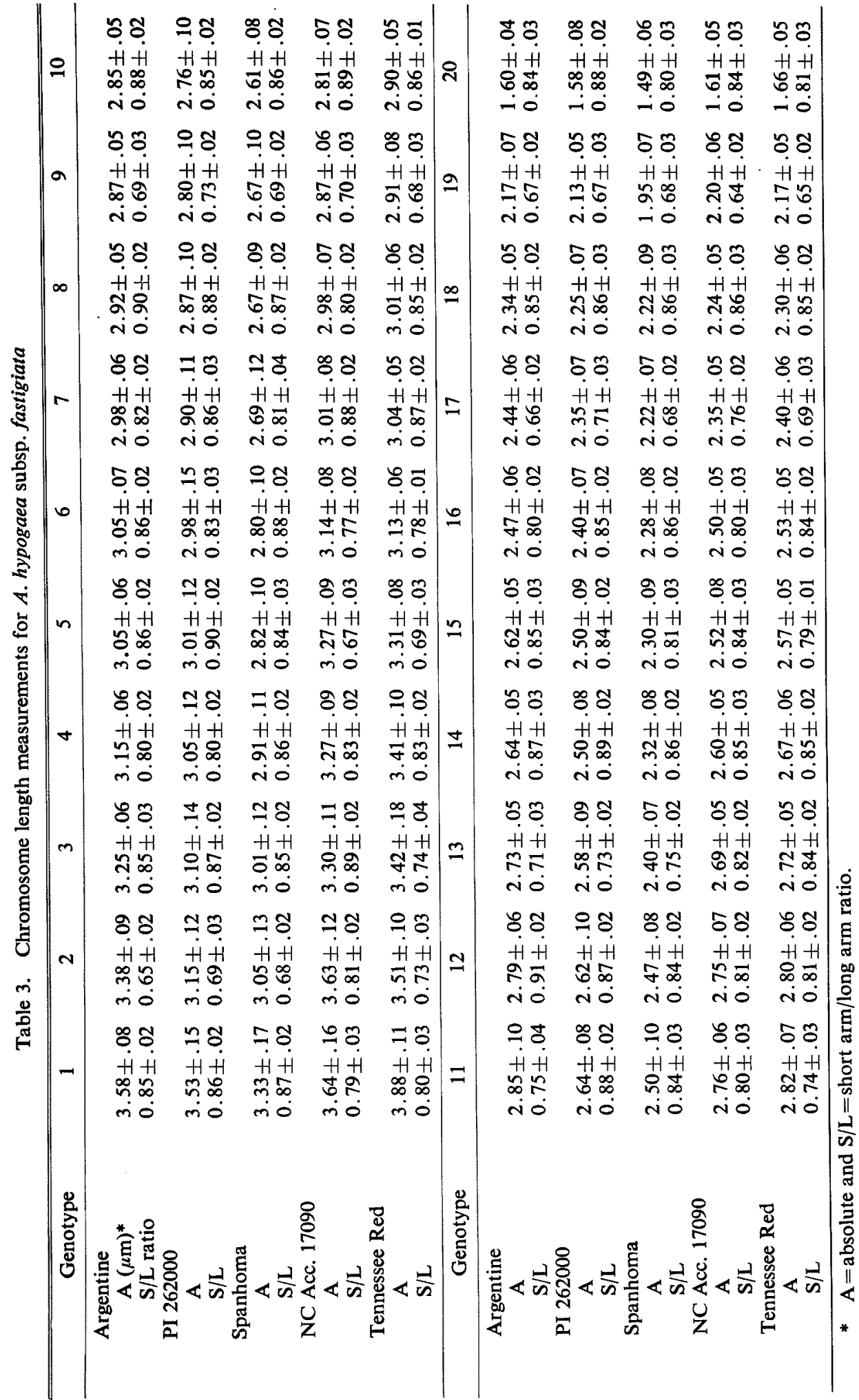


(Table 4). Argentine also had the most distinctive heterochromatic regions among all the genotypes analyzed. Chromosome 2 had a distinct heterochromatic region on the long arm. Two darkly stained regions were observed on the long arm of chromosome 3. Chromosomes 5 and 15 had distinct heterochromatic regions proximal to the centromere and chromosome $17 \mathrm{had}$ one distinct region in the short arm
$\|$
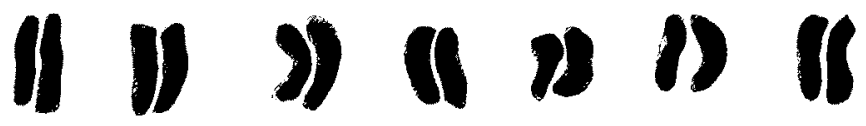
11 )
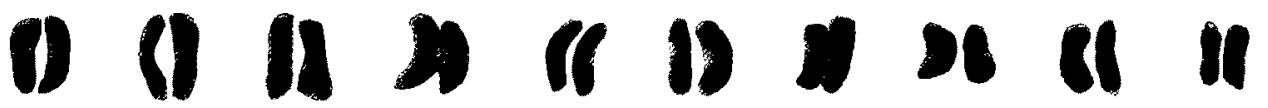
A. HYPOGAEA VAR, HYPOGAEA

\section{1
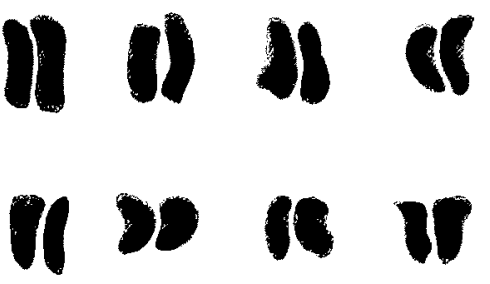
A. HYPOGAEA VAR, HYPOGAEA (NAMBYQUARAE)
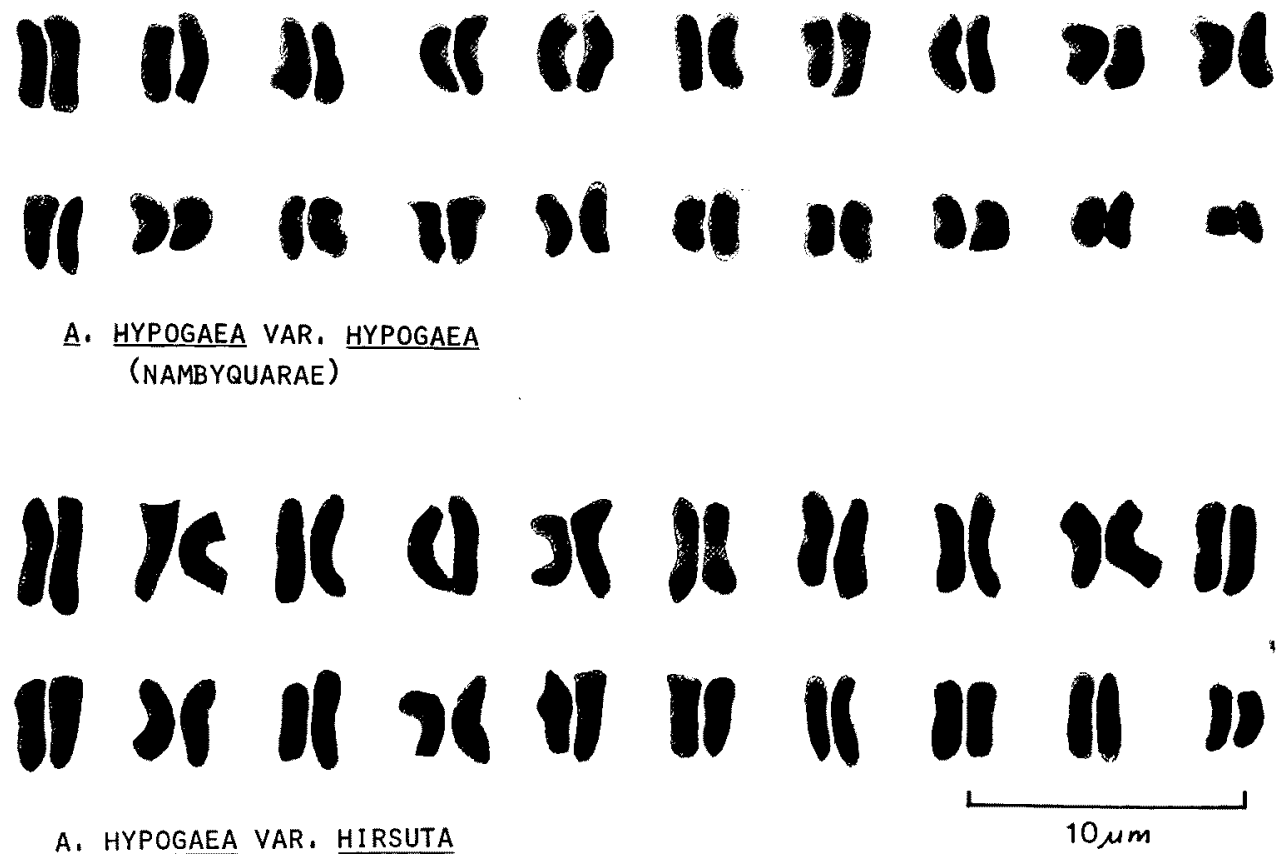
A. HYPOGAEA VAR. HIRSUTA
$10 \mu \mathrm{m}$

Fig. 1. Karyotypes of $A$. hypogaea subsp. hypogaea varieties hypogaea (NC 4 and nambyquarae) and hirsuta (PI 158850).

and two in the long arm. Argentine had 14 median chromosomes and six slightly submedian chromosomes $(2,9,11,13,17$ and 19). The centromere positions of PI 262000 and Spanhoma were very similar to those observed for Argentine, except that these two cultivars had a median chromosome number 11. 
The karyotypes of the two var. fastigiata cultivars (Tennessee Red and NC Acc. 17090) were very similar ( Fg. 3; Tables 3, 4), and the only significant differences were for chromosomes 1,2 and 3 . The two cultivars were the only ones observed with a secondary constriction on one of the longer chromosomes. NC Acc. 17090 had a secondary constriction on chromosome 1 , while it was on chromosome 3 of Tennessee Red. NC Acc. 17090 had 13 median, 6 slightly submedian $(1,5,6,9,11$ and 17) and 1 submedian chromosome (19), while Tennessee Red had 12 median and 8 slightly submedian chromosomes $(2,3,5,6,9,11,17$ and 19).

Table 4. Chromosome variation among A. hypogaea cultivars and A. monticola

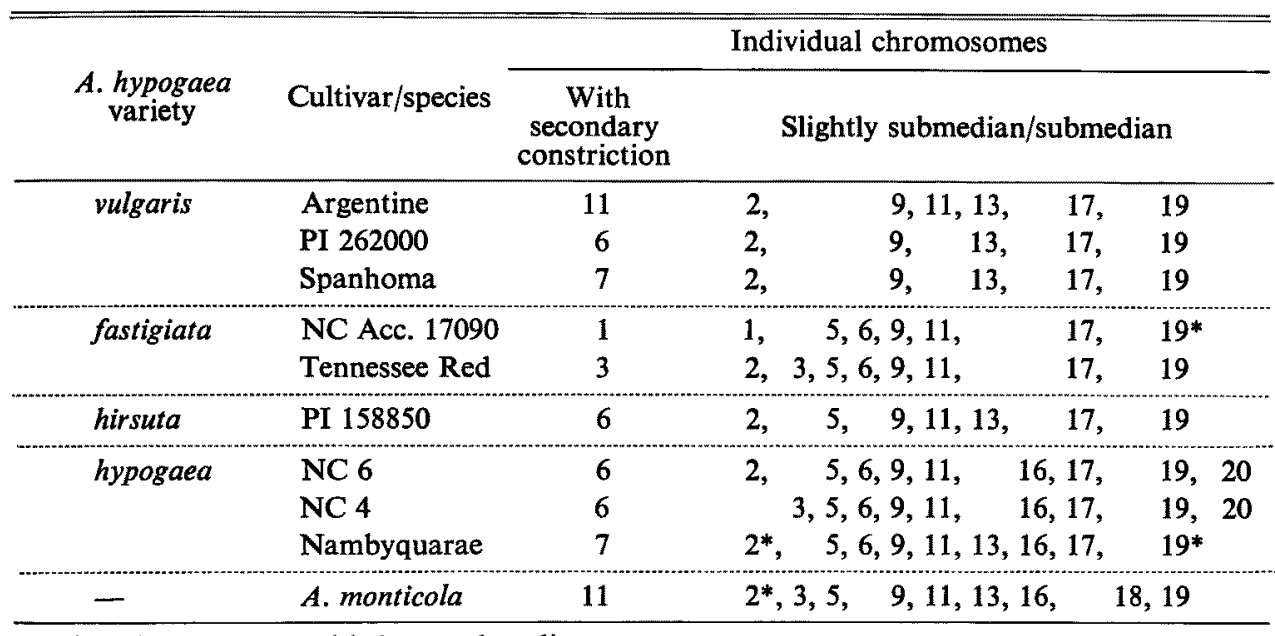

* Chromosomes with * are submedian.

The only representative of subsp. hypogaea var. hirsuta analyzed was PI 158850. This cultivar had the longest genome length- $59.9 \mu \mathrm{m}$ - among all analyzed genotypes. However, the relative chromosome lengths, as measured by the ratio of the chromosomes to number 20 , were very similar to all other cultivars analyzed. When the karyotype was compared to the other varieties, PI 158850 formed a unique group, but was more similar to the subsp. fastigiata cultivars than to members of susp. hypogaea var. hypogaea (Fig. 3; Table 4). PI 158850 had 13 median and seven slightly submedian chromosomes $(2,5,9,11,13,17$ and 19). Chromosome 6 had a recondary constriction.

The two subsp. hypogaea var. hypogaea cultivars, NC 4 and NC 6, had very similar karyotypes. Each cultivar had a secondary constriction on chromosome 6 and slightly submedian chromosomes 5, 6,9,11, 16, 17, 19 and 20. NC 4 and NC 6 had 11 median and 9 slightly submedian chromosomes (Tables 2, 4). The karyotypes of the two North Carolina cultivars were similar except chromosome 2 was median for NC 4, but slightly submedian for NC 6; and chromosome 3 was slightly submedian for NC 4 but median for NC 6 . However, the standard errors of chromosomes 2 and 3 for NC 6 were relatively large (Table 2), and the order for this cultivar could possibly be reversed. NC 4 had two distinct heterochromatic regions in the long arm of chromosome 13, but the darkly stained regions were absent inthe corresponding NC 6 chromosome. Distinct heterochromatic regions 
were also observed in the long arm of chromosome 5 for both NC 4 and NC 6 .

The karyotype of nambyquarae significantly differed from other subsp. hypogaea cultivars analyzed and karyologically grouped with var. fastigiata cultivars (Fig. 3; Table 4). Two distinctive heterochromatic regions were observed on the long arm of both chromosomes 2 and 13 . Eleven chromosomes were median, 7 were slightly submedian and chromosomes 2 and 19 were submedian: Absolute

\section{1
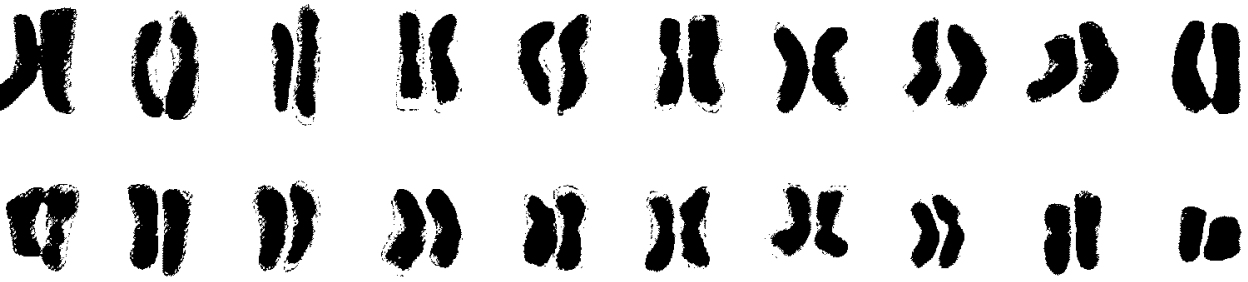

A. MONTICOLA
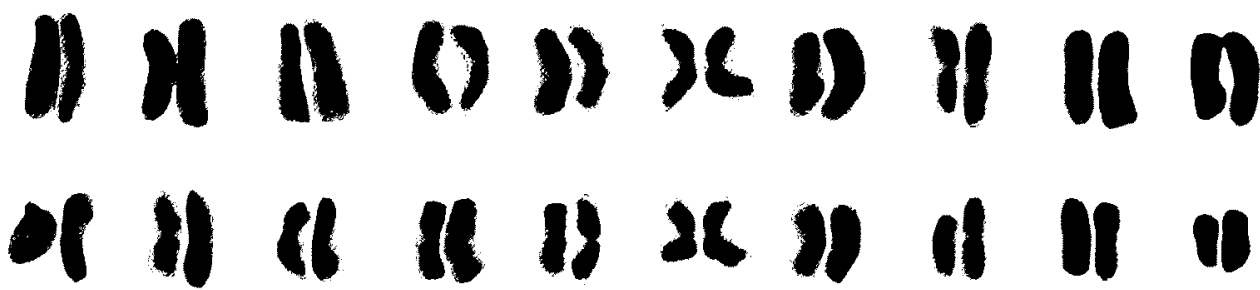
A. HYPOGAEA VAR, VULGARIS (ARGENTINE)

\section{) is
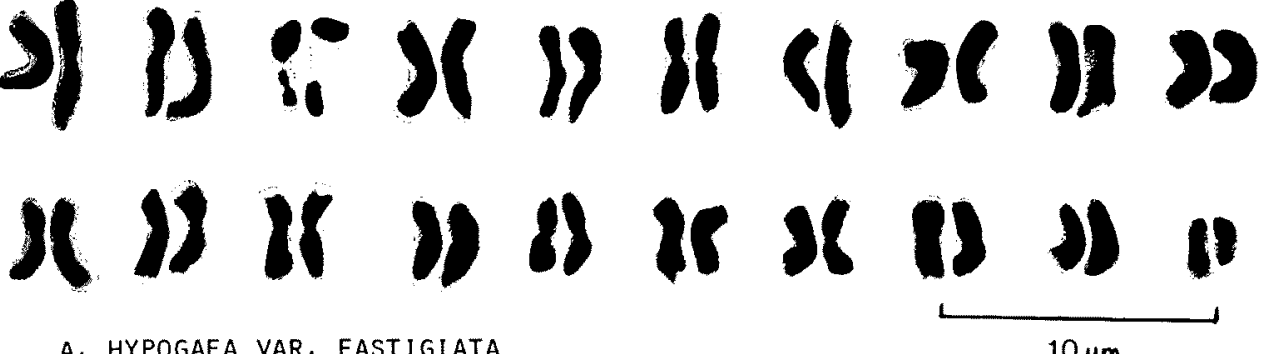 \\ A. HYPOGAEA VAR. FASTIGIATA \\ $10 \mu \mathrm{m}$}

Fig. 2. Karyotypes of $A$. monticola and A. hypogaea subsp. fastigiata varieties vulgaris (Argentine) and fastigiata (Tennessee Red).

chromosome length measurements indicated that nambyquarae had a secondary constriction on chromosome 7. However, the standard deviation of chromosomes 6 and 7 were large (Table 2) and the order of the two chromosomes could possibly be reversed. 
Both $A$. monticola genotypes had the same karyotype, thus only data for collection 7264 is presented in Tables 2 and 4. The A. monticola genotypes had continuous runs of reproductive axes on lateral branches, but no flowers on the main stem. It is thus intermediate between the $A$. hypogaea subsp. hypogaea and fastigiata for flowering patterns. Arachis monticola and Argentine were the only collections analyzed with a secondary constriction on chromosome 11 . Arachis monticola had 11 median and 8 slightly submedian chromosomes and a submedian

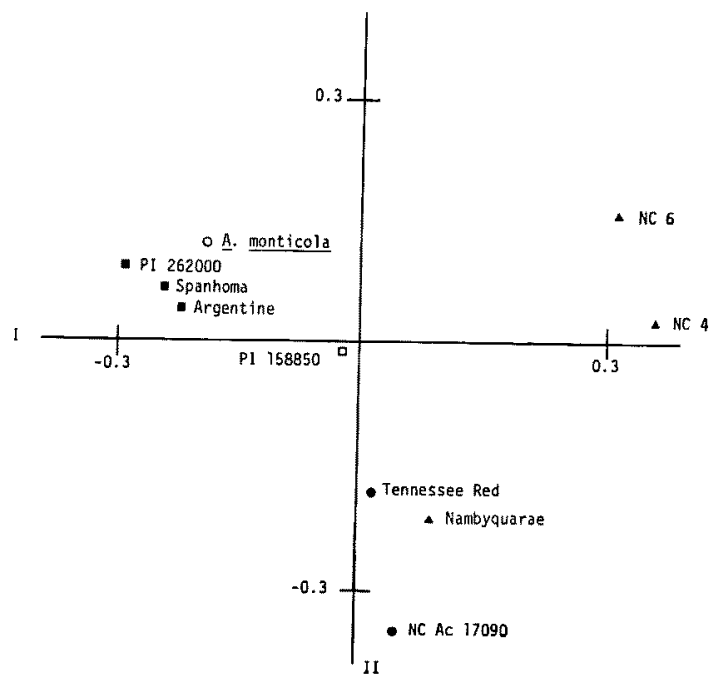

Fig. 3. Scatter diagram of nine A. hypogaea cultivars and $A$. monticola which were separated by principal components of chromosome arm ratios.

chromosome number 2. The species differed from A. hypogaea by having a median rather than a slightly submedian chromosome 17 and the reverse was true for chromosome 18. Chromosome 17 for $A$. monticola averaged $2.44 \pm .04 \mu \mathrm{m}$ while chromosome 18 averaged $2.38 \pm .04 \mu \mathrm{m}$, so the chromosome order is believed to be correct as presented and truly different from the cultivated species.

\section{Discussion}

The chromosomes of A. hypogaea are small, ranging from 1.49 to $4.16 \mu \mathrm{m}$ in the cultivars analyzed. While most chromosome pairs are easily distinguishable when they are not highly condensed or overstained, several homologues are nearly identical. Most problems in identification were experienced when a series of metacentric chromosomes with nearly the same lengths were observed. For example, chromosomes 14 and 15 of Argentine were 2.64 and $2.62 \mu \mathrm{m}$ long and had arm ratios of 0.87 and 0.84 , respectively. The heterochromatic regions were also similar and chromosome identification is nearly impossible. A similar problem was observed for chromosomes 5 and 6 of Argentine because both chromosomes had a length of $3.05 \mu \mathrm{m}$ and arm ratios of 0.86 . However, chromosome 5 had one heterochromatic region proximal to the centromere on the short arm while chromosome 6 had one proximal and one distal heterochromatic region.

The karyological groups of cultivars (Fig. 3) generally correspond to the varietal classification proposed by Krapovickas (1969). Even though members of varieties vulgaris, fastigiata and hypogaea are cytologically unique, varieties vulgaris and hypogaea represent the karyological extreme groups while the other botanical varieties are intermediate. The karyological data agree with Gregory et al. (1973) who gave nambyquarae varietal status. The cultivars nambyquarae and PI 158850 are 
karyologically most closely related to var. fastigiata and from this investigation it appears that cultivars of varieties hirsuta and fastigiata (and nambyquarae) may have been of hybrid origin between ancient var. hypogaea and var. vulgaris genotypes. Isleib (1982) reported a principal component analysis using 21 morpholgical chraracters and 28 cultivars, including nambyquarae and PI 158850. In his morphological study, nambyquarae was significantly different from all other genotypes while PI 158850 clustered with var. vulgaris genotypes. Additional collections need to be analyzed, especially of var. hirsuta, before true phylogenetic relationships of this group are verified. Although meiotic studies have previously indicated little genomic differentiation among varieties (Stalker 1980), the analysis has revealed a significant and unexpected amount of chromosomal variation among cultivars of A. hypogaea. Five different chromosomes with secondary constrictions were observed among the genotypes ranging from the largest chromosome for NC Acc. 17090 to one of the smaller chromosomes for Argentine. If all the genotypes had a common ancestor, as is commonly believed, then structural rearrangements probably were the result of translocations and subsequent varietal differentiation. A standard karyotype is not being proposed for the species as a whole because of the observed chromosome variation. However, in all nine cultivars the chromosomes $4,8,10,12,14,15$ and 18 were median and nearly identical, and chromosomes 9 and 19 were slightly submedian to submedian and very similar. Variation was observed among genotypes for the remaining $11 \mathrm{~A}$. hypogaea chromosomes. Patterns of variation were apparent within botanical varieties and the cultivars illustrated in Figs. 1 and 2 are proposed as standard karyotypes for each group and A. monticola. Identification of the $A$. hypogaea chromosomes was sufficient to develop cytogenetic stocks (such as aneuploid series) for specific cultivars.

The primary center for domestication of peanuts is probably southern Bolivia or northern Argentina (Gregory and Gregory 1976, Krapovickas 1969). Members of subsp. hypogaea var. hypogaea are the predominant peanut type in this region and believed to be most closely related to the wild Arachis species because var. hypogaea usually has a runner habit, a similar branching pattern as other Arachis species and does not have compound spikes (Krapovickas 1969). Although Husted (1936) proposed that $A$. hypogaea is of direct amphidiploid origin, Krapovickas and Rigoni (1957) and Smartt and Gregory (1967) suggested that the cultivated species evolved from a pre-existing wild allotetraploid which probably arose from an annual $\times$ perennial interspecific hybrid within section Arachis (Gregory and Gregory 1976). Since A. monticola is the only other known tetraploid species in section Arachis, this is the most likely candidate for the direct progenitor of $A$. hypogaea. The $A$. monticola collections used in this investigation were collected from northern Argentina and no cultivars were observed in the area (Gibbons et al. 1972). While K 7264 has been in germplasm nurseries for many years, collection GKBSPSc 30062 was only grown in the greenhouse after introduction from South America. If $A$. monticola is the progenitor of the cultivated species and if var. hypogaea is the most closely related cultivated type, as previously suggested (Krapovickas and Rigoni 1957), then similar karyotypes should be observed for the two groups. However, the conclusion drawn from the karyological analyses of $A$. monticola and A. hypogaea 
varieties is that $A$. monticola is most closely related to var. vulgaris. Thus, based strictly on the karyological data, the members of subsp. fastigiata var. vulgaris appear to be the ancestral $A$. hypogaea type.

Several diploid species of section Arachis have been suggested as possible progenitors to A. hypogaea, including A. villosa Benth. (Varisai Muhammad 1973), A. duranensis Krap. et Greg. nom. nud. (Seetharam et al. 1973), A. batizocoi Krap. et Greg. (Karpovickas et al. 1974), A. duranensis and A. cardenasii Krap. et Greg. nom. nud. (Gregory and Gregory 1976) and A. cardenasii and A. batizocoi (Smartt et al. 1978a, 1978b). When the karyotypes of above species as reported by Stalker and Dalmacio (1982) are compared with the karyotypes of $A$. hypogaea, several conclusions can be drawn. First, $A$. hypogaea has a symmetrical karyotype with mostly median chromosomes but several diploid species (i.e., A. batizocoi and A. cardenasii) each has as many as seven slightly submedian or submedian chromosomes. Since the number of asymmetrical chromosomes in the tetraploid species ranged from 5 in PI 262000 and Spanhoma to 9 in NC 6 and $A$. monticola, it is unlikely that two diploid species such as $A$. batizocoi and $A$. cardenasii hybridized to eventually become the progenitors of $A$. hypogaea. The other species hypothesized as progenitors of cultivated peanuts, $A$. villosa or $A$. duranensis, have two and three submedian or slightly submedian chromosomes, respectively. The karyotype of either species can be superimposed over the karyotype of $A$. hypogaea. The karyotypic data so far collected have not confirmed or eliminated possible progenitors of the cultivated peanut. However, the data can be used to eliminate unlikely species combinations such as $A$. cardenasii $\times A$. batizocoi. As additional genotypes are analyzed and more refined techniques utilized, the evolutionary patterns of the cultivated peanut and related species will become more apparent.

\section{Summary}

Mitotic chromosomes of nine Arachis hypogaea L. cultivars plus A. monticola Krap. et Rig. were analyzed cytologically. The cultivars included representatives of the four botanical varieties of $A$. hypogaea. The objective of this investigation was to identify the chromosomes of cultivated peanuts and determine the variation among subspecies and varieties. The $A$. hypogaea chromosomes ranged in length between 1.44 and $4.17 \mu \mathrm{m}$ and were mostly metacentric. Variation was observed in the numbers of asymmetrical chromosomes per cultivar and in the chromosome with a secondary constriction. Based on heterochromatic regions, centromere positions, and chromosome lengths, homologues were identified and ordered from $1=$ longest to $20=$ shortest. Although each genotype had a unique karyotype, patterns of variation were observed and all $A$. hypogaea varieties were cytologically distinguished. Varieties vulgaris and hypogaea were karyologically the extreme groups with other varieties being intermediate. The cultivar nambyquarae is grouped karyologically with var. fastigiata even though it is a member of subspecies hypogaea. Arachis monticola was karyologically more similar to variety vaulgaris than other groups of $A$. hypogaea. This suggests that the variety vulgaris cultivars may be the most ancient $A$. hypogaea group. 


\section{Literature cited}

Babu, C. N. 1955. Cytogenetical investigations on groundnuts $I$. The somatic chromosomes. Indian J. Agr. Sci. 25 : $41-46$.

D'Cruz, R. and Tankasale, M. P. 1961. A note on chromosome complement of four groundnut varieties. Indian Oilseeds J. 5: 58-59.

Ghimpu, V. 1930. Recherches cytologiques sur les genes: Hordeum, Acacia, Medicago, Vitis et Quercus. Arch. d'Anat. Microsc. 26: 136-234.

Gibbons, R. W., Bunting, A. H. and Smartt, J. 1972. The classification of varieties of groundnut (Arachis hypogea L.). Euphytica 21: 78-85.

Gregory, W. C. and Gregory, M. P. 1976. Groundunt, Arachis hypogaea (Leguminosae-Papilionatae). In Evolution of Crop Plants. N. W. Simmonds, Ed. Longman, London and New York. p. 151-154.

-, -, Krapovickas, A., Smith, B. W. and Yarbrough, J. A. 1973. Structure and genetic resources of peanuts, Chapter 3. In Peanuts-Culture and Uses. Amer. Peanut Res. Educ. Assoc., Stillwater, Okla. p. 47-133.

-, Krapovickas, A. and Gregory, M. P. 1980. Structures, variation, evolution and classification in Arachis. In Advances in Legume Science, Vol. 1. R. J. Summerfield and A. H. Bunting, Eds. International Legume Conference, Royal Botanic Gardens, Kew. p. 469-481.

Husted, L. 1933. Cytological studies of the peanut Arachis I. Chromosome number and morphology. Cytologia 5: 109-117.

- 1936. Cytological studies of the peanut Arachis II. Chromosome number, morphology and behaviour and their application to the origin of cultivated forms. Cytologia 7: 396-423.

Isleib, T. G. 1982. Heterosis and early generation testing in testcrosses of exotic peanut (Arachis hypogaea L.) cultivars. Ph. D. Dissertation, N. C. State Univ., Raleigh. 84 p.

Krapovickas, A. 1969. Origen, variabilidad y difusión del mani (Arachis hypogaea). In The Domestication and Exploitation of Plants and Animals. P. J. Ucko and G. W. Dimbleby, Eds. London. p. 427-441.

- 1973. Evolution of the genus Arachis. In Agricultural Genetics, Selected Topics. R. Moav, Ed. National Council for Research and Development, Jerusalem. p. 135-151.

-, Fernandez, A. and Seeligman, P. 1974. Recuperación de la fertilidad en un híbrido interspecifico estéril de Arachis (Leguminosae). Bonplandia 3: 129-142.

- and Rigoni, V. A. 1957. Nuevas especies de Arachis vinculadad al problema del origen del mani. Darwiniana 11: 431-455.

Seetharam, A., Nayar, K. M. D., Sreekantaradhyal, R. and Achar, D. K. T. 1973. Cytological studies on interspecific hybrids of Arachis hypogaea $\times$ Arachis duranensis. Cytologia 38: 277-280.

Singh, A. K. and Moss, J. P. 1982. Utilization of wild relatives in genetic improvement of Arachis hypogaea L. Part 2: Chromosome complements of species in section Arachis. Theor. Appl. Genet. 61: 305-314.

Smartt, J. and Gregory, W. C. 1967. Interspecific cross-compatibility between the cultivated peanut Arachis hypogaea L. and other members of the genus Arachis. Oleagineux 22: $455-459$.

-, - and Gregory, M. P. 1978a. The genomes of Arachis hypogaea. 1. Cytogenetic studies of putative genome donors. Euphytica 27: 665-675.

-, - and - 1978b. The genomes of Arachis hypogaea. 2. The implications in interspecific breeding. Euphytica 27: 677-680.

- and Stalker, H. T. 1982. Speciation and cytogenetics of Arachis. In Peanut Science and Technology. H. Pattee and C. Young, Eds. Am. Peanut Res. and Educ. Soc., Yoakum, Tex. p. 21-49.

Stalker, H. T. 1980. Cytogenetic investigations in the genus Arachis. ICRISAT Proc. of the Internat. Workshop on Groundnuts, Oct. 13-17, 1980, Patancheru, A. P., India. p. 73-81. - and Dalmacio, R. D. 1981. Chromosomes of Arcahis species, section Arachis (Leguminosae).
J. Hered. 72: 403-408. 
Varisai Muhammad, S. 1973. Cytological investigations in the genus Arachis L. II. Triploid hybrids and their derivatives. Madras Agric. J. 60: 1414-1427.

Wynne, J. C. 1974. Breeding potential of the subspecies of Arachis hypogaea L.: Inheritance of branching pattern, estimates of combining ability and photoperiodic response. $\mathrm{Ph} . \mathrm{D}$. Dissertation, N. C. State Univ., Raleigh. 103 p.

- and Gregory, W. C. 1981. Peanut breeding. Adv. in Agron. 34: 39-72. 